\title{
Effect of Palm Oil Fiber (POF) to Strength Properties and Fracture Energy of Green Concrete
}

\author{
(Date received: 4.8.2018/Date accepted: 6.8.2018)
}

\author{
Abdul Aziz Abdul Samad*, Cindy Wong Yean Theng, Tim Ee Ching, Noridah Mohamad, \\ Muhammad Afiq Tambichik and Mohamad Zulhairi Mohd Bosro
}

\author{
Faculty of Civil and Environmental Engineering, Universiti Tun Hussein Onn Malaysia \\ *Corresponding Author: azizs@uthm.edu.my
}

\section{ABSTRACT}

The lack of research on concrete which utilizes Palm Oil Fuel Ash (POFA), Rice Husk Ash (RHA), Recycled Concrete Aggregate (RCA) and Palm Oil Fiber (POF) simultaneously in concrete was globally observed. To meet this gap, a study on green concrete consisting of POFA, RHA and RCA with added untreated POF as binders was conducted. The study focusses on the effect of varying percentages of untreated POF, ranging from $0 \%, 0.25 \%, 0.50 \%$ and $0.75 \%$, to the strength properties and fracture energy of green concrete. The strength properties of green concrete were investigated by conducting the compression strength test and tensile strength test on forty-eight (48) cubes and cylinders at the curing age of 7 and 28 days. The tests show that the strength of green concrete decreases, as the percentage of POF increases. This was preceded by the establishment of an optimum percentage of POF at $0.25 \%$. The fracture energy of the green concrete was determined by testing twelve numbers of notched beams with dimensions of $100 \mathrm{~mm} \times 100 \mathrm{~mm} \times 500 \mathrm{~mm}$ under the three-point bending test. From the threepoint bending test, the load-deflection profile for each specimen with different percentages of untreated POF was obtained. Three existing theoretical models, namely Hillerborg, Bazant and CEB models were used to measure the fracture energy of the green concrete with varying percentage of fiber. Results range from $37.94 \mathrm{~N} / \mathrm{m}$ to $153.81 \mathrm{~N} / \mathrm{m}$ was observed. The study also successfully established the reliability of Hillerborg's model to fracture energy when models by Bazant and CEB surprisingly shows a decrease in fracture energy measurements with increase in fiber content.

Keywords: Fracture Energy, Green Concrete, Palm Oil Fuel Ash, Palm Oil Fiber, Recycled Concrete Aggregate, Rice Hush Ask, Strength Properties

\subsection{INTRODUCTION}

The government of Malaysia encourages the construction industry (by offering incentives) to promote the growth of sustainable development by environmentally friendly and sustainable resources [1]. Adopting the concept of using green materials is important to make sure that the irreversible environmental impact due to construction can be mitigated. Therefore, the selection of material used in the production of green concrete may act as the strategy in constructing the ecofriendly building. Malaysia is a tropical country with generous rainfall which favours the growth of an agriculture sector. Hence, the palm oil industry of Malaysia is one of the largest producers and exporters in the world. However, this also means that Malaysia is also producing many amounts of agriculture waste from the palm oil industry. The wastes from palm oil have good potential for producing green concrete by further processing the empty fruit bunches, fibers and shells of the palm oil. Through burning of palm oil agriculture waste including fibers, shells and empty fruit bunches as fuel in palm oil mill boilers a byproduct called Palm Oil Fuel Ash or POFA is obtained. POFA, with its pozzolanic properties, can be used as a supplementary cementitious material for the production of concrete with good workability rate and high strength concrete. Another agriculture waste which contributes to the development of green concrete is Rice Husk Ash or RHA. Rice husk is generated from the rice milling industry during the milling of paddy. In the combustion process, a carbon neutral green material called RHA is produced with super-pozzolan characteristics. The growing demand on fine amorphous silica encourages this super-pozzolan RHA to be used for producing green concrete with high strength but low permeability. Industrial experts have also recognized the value in breathing new life from old concrete known as recycled concrete aggregate or RCA. Countless concrete structures are being demolished each year for several purposes such as refurbishment, renovation and repairing work. Hence, recycling the concrete is an effort to reduce the amount of raw materials needed to produce stone aggregate at the same time saving the waste concrete ended up in a landfill which pollute the environment. RCA materials are thoroughly screened to remove any metal, scrap or other impurities. It is then crushed down to a smaller aggregate size so that it can be repurposed for other construction and landscaping purposes. Therefore, production of green concrete is innovative as it makes good use of waste materials as part of its components.

\subsection{LITERATURE REVIEW}

To address the sustainability of the environment, three specific issues have been identified by the Construction Industry Development Board (CIDB). These issues are lack of 


\section{EFFECT OF PALM OIL FIBER (POF) TO STRENGTH PROPERTIES AND FRACTURE ENERGY OF GREEN CONCRETE}

sustainability-rated construction; buildings and infrastructure are not always resilient to natural calamities, high carbon emissions and energy usage of buildings and high volume of construction and demolition waste dumping. To safeguard the environment, many efforts are being made by recycling agricultural wastes and construction wastes, hence green concrete is introduced into the construction industry.

Today, pozzolanic materials are widely used as supplementary cement materials in the making of high strength concrete. There are many common types of pozzolans which are globally used as a replacement for Portland cement and an additive in concrete. It is well-known that the filler effect and the pozzolanic reaction contributes to the strength of pozzolanic concrete. Besides that, the pozzolan contains siliceous materials. The "high early strength" concrete are produced by highly reactive silica in pozzolans when combined with calcium hydroxide to give the cementitious properties [1].

Based on the research, the review of the strength properties of hardened concrete which uses POFA as an additive including compressive strength and splitting tensile strength is explained. Replacement of Portland cement with 10-50\% of POFA while maintaining the water to cement of 0.6 was studied by most researchers as reported by [2]. From the study, it was found that as the amount of POFA increases, the compressive strength of the concrete decreases. The researchers concluded that $10 \%$ was the best level of POFA replacement to avoid interruption of the strength formation in concrete during the curing process. This was proven when the compressive strength testing of lightweight foamed concrete containing $10 \%$ and $20 \%$ of POFA was measured at $7.17 \mathrm{MPa}$ and $7.06 \mathrm{MPa}$ respectively at 90 days curing. Yet, the control concrete specimen only gives the strength of 6.50MPa. For the split tensile testing containing the same percentage of $10 \%$ and $20 \%$ of POFA, the specimens were observed to meet a higher strength by $19 \%$ and $9 \%$ when compared to the control specimen at 90 days. The observation was due to the formation of extra calcium silicate hydrate (C-S-H) gel due to the pozzolanic reaction by POFA enhanced the bonding of the specimen.

Reports by [3] have shown that the raw rice husk consists of about $40 \%$ cellulose, $30 \%$ lignin group and $20 \%$ silica. Commonly, the RHA is produced when cellulose lignin matrix of raw rice husk was burned away and left the porous silica skeleton upon combustion. After grinding the porous silica skeleton of rice husk, rice husk ash (RHA) is produced in the form of a fine powder with the high surface area and its highly reactive pozzolanic material due to its high silica content. Sandhu and Siddique [4] concluded the strength properties of self-compacting concrete (SCC) with the addition of RHA. The researchers [4] concluded that $10 \%-15 \%$ of RHA contribute to the significant influence on the concrete strength properties. At 28 days, a range of compressive strength between $36.7 \mathrm{MPa}$ and 41.2 MPa was achieved. Similarly, the strength of $39.6-46.4$ $\mathrm{MPa}$ was observed on 56 days with $10-20 \%$ RHA of water to binder ratio of 0.41 contained in the SCC mix. From the study, $15 \%$ of RHA mix attained the largest value of compressive strength, whereas SCC control mix gives a strength of less than $20 \%$ of RHA mixed with 56 days curing. This phenomenon was due to the presence of calcium silicate hydrates through the reaction with water and calcium hydroxide by highly reactive RHA particles. Another observation includes $15 \%$ replacement of RHA increases the strength properties of split tensile.
It was found that the substitution of RCA up to $30 \%$ of virgin aggregate shows similar compressive strength as normal concrete. As for tensile strength, the substitution of RCA on concrete reduces the value by $10 \%$. The tensile strength of concrete was said to be more dependent on the binder quality rather than the aggregate used [5].

The 3rd ACF International Conference [6], established that $\mathrm{POF}$, as a natural fiber, was a suitable binder due to its ability to improve the tensile strength of concrete materials. These concrete material with added POF was also found to be a good fire resistant material with high durability. The main intention to incorporate POF into concrete was to yield reinforcement and delay the growth of cracks by improving the tensile strength. Besides that, it helps to transmit stress across the cracked section in order to achieve larger deformation possible beyond its peak stress. The lengths of POF used ranges from $1-5 \mathrm{~cm}$ of the fiber to avoid the fiber balling effect resulting in an uneven distribution throughout the concrete [7]. To avoid the balling effect, research has shown that the percentage of fiber was normally added in the range of $0.25 \%, 0.50 \%$ and $0.75 \%$ [8].

The impact of adding untreated POF towards the performance of green concrete against cracking resistance could be measured by fracture energy [9]. Fracture energy is the amount of energy required to create one unit area of crack and it is one of the important parameters that characterize concrete fracture. Fracture energy is the area under the load-deflection curve per unit fracture area. To enhance the crack resistance of green concrete, untreated palm oil fiber is added. The main aim of this research was to determine the fracture energy of green concrete with varying percentage of palm oil fiber. Therefore, the effect of adding palm oil fiber to the fracture energy was investigated by carrying out a series of experimental works using the three-point bending test.

\subsection{FRACTURE ENERGY}

Fracture energy is the most important parameter that governs the cracking and failure of a certain structure. The value of fracture energy can be determined by using Hillerborg's model [10], Bazant model [11] and Comite Euro-International du Beton (CEB) model [12].

Hillerborg model [10] is the fundamental model that had been used in analyzing the fracture energy for mortar and concrete. The fracture energy for concrete is based on area under the load-deflection curve as follow:

$G_{F}=\frac{W_{o}+m_{g} \delta_{f}}{B\left(D-a_{o}\right)}$

where, $W_{o}$ is area under load versus deflection curve, $m_{g}$ is mass of beam, $\delta_{f}$ is maximum deflection, $B$ is width of the specimen, $D$ is depth of the specimen and $a_{o}$ is notch depth.

Bazant [11] proposed a simple formula to determine the fracture energy of concrete. The formula includes compressive strength and water-cement ratio as follow:

$G_{F}=2.5 \alpha_{o} \times\left(\frac{f_{c}}{0.058}\right)^{0.4}\left(1+\frac{D_{\max }}{1.94}\right)^{0.43}\left(\frac{w}{c}\right)^{-0.18} \mathrm{~N} / \mathrm{m}$

where, $\alpha_{o}$ is aggregate size factor which is 1 for rounded aggregate and 1.44 for angular aggregate, $D_{\max }$ is maximum aggregate size, $f_{c}$ is compressive strength of concrete, $\left(\frac{w}{c}\right)$ is water-cement ratio. 


\section{ABDUL AZIZ ABDUL SAMAD, CINDY WONG YEAN THENG, TIM EE CHING, NORIDAH MOHAMAD, MUHAMMAD AFIQ TAMBICHIK AND MOHAMAD ZULHAIRI MOHD BOSRO}

Fracture energy of concrete can also be determined using Comite Euro-International du Beton (CEB) model [12]. CEB model consider the maximum aggregate size and compressive strength of concrete in calculating fracture energy. Formula proposed by CEB is as follow:

$$
G_{F}=\left[0.0469\left(D_{\max }\right)^{2}-0.5 D_{\max }+26\right] \times\left(\frac{f_{c}}{10}\right)^{0.7} \mathrm{~N} / \mathrm{m}
$$

where, $D_{\max }$ is maximum aggregate size and $f_{c}$ is compressive strength of concrete.

\subsection{MATERIALS}

\subsection{Raw Materials}

For this study, the green concrete comprises of four waste materials made from POFA, RHA, RCA and POF, see Figure 1. All the agricultural wastes and construction wastes was collected from different sources. Both POFA and POF were obtained from Bell Oil Palm Plantation located at Parit Sulong, Johor. Whilst RHA was collected from the rice milling factory at Jelapang Selatan, Muar, Johor. Lastly, RCA were obtained from crushed concrete cubes and cylinders available at the Heavy Structures Laboratory, Universiti Tun Hussein Onn Malaysia. To complete the green concrete mix, Portland cement Type 1, sand of saturated surface dry (SSD) condition and natural coarse aggregate with sieve size of 5-9 $\mathrm{mm}$ were used.

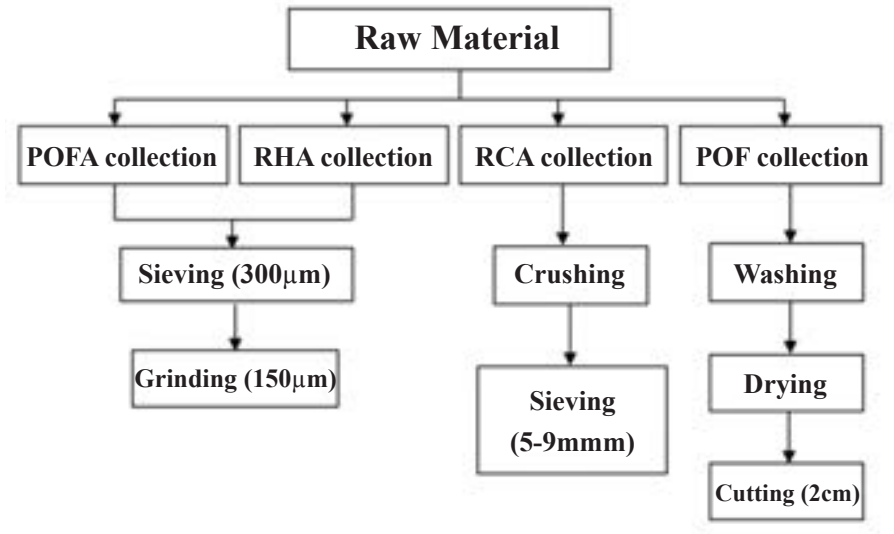

Figure 1: Preparation of Raw Materials

\subsection{Concrete Mix Design}

The targeted design strength of $30 \mathrm{MPa}$ was employed. The green concrete mix design, as shown in Table 1, was adopted from the American Concrete Institute ACI 211.1 Standard [13]. A total of 48 specimens were cast which consists of 24 cubes of size $100 \mathrm{~mm} \times 100 \mathrm{~mm} \times 100 \mathrm{~mm}$ and 24 cylinders of size $100 \mathrm{~mm}$ $\mathrm{x} 200 \mathrm{~mm}$. There were in total four types of mixtures proposed, namely MC, M1, M2 and M3 with POF at $0 \%, 0.25 \%, 0.50 \%$ and $0.75 \%$ respectively. The specimens were subjected to water curing upon 24 hours of casting and tested at 7 days and 28 days strength. The concrete mixtures for MC, M1, M2 and M3 are as illustrated in Table 2 for cubes and Table 3 for cylinders.
Table 1: Green Concrete Mix Design

\begin{tabular}{|c|c|c|c|c|}
\hline \multicolumn{5}{|c|}{ Mix Design } \\
\hline Quantity & $\begin{array}{c}\text { Cement } \\
\left(\mathbf{k g} / \mathbf{m}^{3}\right)\end{array}$ & $\begin{array}{c}\text { Fine Aggregate } \\
\left(\mathbf{k g} / \mathbf{m}^{3}\right)\end{array}$ & $\begin{array}{c}\text { Coarse Aggregate } \\
\left(\mathbf{k g} / \mathbf{m}^{3}\right)\end{array}$ & Water $\left(\mathbf{k g} / \mathbf{m}^{3}\right)$ \\
\hline $1 \mathrm{~m}^{3}$ & 400 & 872 & 688 & 228 \\
\hline
\end{tabular}

Table 2: Compressive Strength

\begin{tabular}{|c|c|c|c|c|c|c|c|c|}
\hline Mixture & $\begin{array}{c}\text { Cement } \\
(\mathbf{k g})\end{array}$ & $\begin{array}{c}\text { RHA } \\
(\mathbf{k g})\end{array}$ & $\begin{array}{c}\text { POFA } \\
(\mathbf{k g})\end{array}$ & $\begin{array}{c}\text { RCA } \\
\mathbf{( k g )}\end{array}$ & $\begin{array}{c}\text { Coarse } \\
\text { Aggregate } \\
(\mathbf{k g})\end{array}$ & $\begin{array}{c}\text { Sand } \\
(\mathbf{k g})\end{array}$ & $\begin{array}{c}\text { Water } \\
(\mathbf{k g})\end{array}$ & $\begin{array}{c}\text { POF } \\
(\mathbf{k g})\end{array}$ \\
\hline MC & 0.300 & 0.060 & 0.040 & 0.138 & 0.550 & 0.872 & 0.256 & - \\
\hline M1 & 0.300 & 0.060 & 0.040 & 0.138 & 0.550 & 0.872 & 0.256 & 0.001 \\
\hline M2 & 0.300 & 0.060 & 0.040 & 0.138 & 0.550 & 0.872 & 0.256 & 0.002 \\
\hline M3 & 0.300 & 0.060 & 0.040 & 0.138 & 0.550 & 0.872 & 0.256 & 0.003 \\
\hline
\end{tabular}

Note: $M C$ - Control specimen

Table 3: Split Tensile Strength

\begin{tabular}{|c|c|c|c|c|c|c|c|c|}
\hline Mixture & $\begin{array}{c}\text { Cement } \\
(\mathbf{k g})\end{array}$ & $\begin{array}{c}\text { RHA } \\
(\mathbf{k g})\end{array}$ & $\begin{array}{c}\text { POFA } \\
(\mathbf{k g})\end{array}$ & $\begin{array}{c}\text { RCA } \\
\mathbf{( k g )}\end{array}$ & $\begin{array}{c}\text { Coarse } \\
\text { Aggregate } \\
\mathbf{( k g )}\end{array}$ & $\begin{array}{c}\text { Sand } \\
\mathbf{( k g )}\end{array}$ & $\begin{array}{c}\text { Water } \\
(\mathbf{k g})\end{array}$ & $\begin{array}{c}\text { POF } \\
(\mathbf{k g})\end{array}$ \\
\hline MC & 0.471 & 0.094 & 0.063 & 0.216 & 0.864 & 1.369 & 0.401 & - \\
\hline M1 & 0.471 & 0.094 & 0.063 & 0.216 & 0.864 & 1.369 & 0.401 & 0.002 \\
\hline M2 & 0.471 & 0.094 & 0.063 & 0.216 & 0.864 & 1.369 & 0.401 & 0.003 \\
\hline M3 & 0.471 & 0.094 & 0.063 & 0.216 & 0.864 & 1.369 & 0.401 & 0.005 \\
\hline
\end{tabular}

Note: MC - Control specimen

\subsection{TESTING METHOD}

\subsection{Material Tests}

The slump test was conducted to examine the fresh properties of green concrete. The testing for hardened concrete comprises of it's harden density, compressive strength and split tensile strength. Table 4 list the codes of practises on which the respective test procedures on fresh and hardened concrete was conducted.

Table 4: Code of Practise for the Hardened Concrete Testing

\begin{tabular}{|c|l|l|l|}
\hline No. & $\begin{array}{l}\text { Properties } \\
\text { of Concrete }\end{array}$ & \multicolumn{1}{|c|}{ Type of Testing } & Codes of Practise \\
\hline 1. & $\begin{array}{l}\text { Fresh } \\
\text { Concrete }\end{array}$ & Slump Test & $\begin{array}{l}\text { ASTM C143/C143M-15 } \\
{[14]}\end{array}$ \\
\hline 2. & & Hardened Density & BS EN 12390-7:2009 [15] \\
\cline { 4 - 5 } 3. & Hardened & Compressive Strength Test & BS EN 12390-3:2009 [16] \\
\cline { 4 - 5 } 4. & Concrete & Split Tensile Strength Test & $\begin{array}{l}\text { ASTM C496/C496M - 04 } \\
{[17]}\end{array}$ \\
\hline
\end{tabular}

\subsection{Three Point Bending Tests}

Three point bending test on V-notched prisms was adopted to determine the fracture energy of green concrete. The prism specimen size of $100 \mathrm{~mm} \times 10 \mathrm{~mm} \times 500 \mathrm{~mm}$ (Figure 2) and the testing method for three point bending test was proposed in reference to ASTM E1820 [18]. Three point bending test was prepared by resting the beam on roller supports and applied point load in the middle span of the beam where the notch was located, see Figure 3. The point load was applied at a rate of $0.5 \mathrm{~mm} / \mathrm{min}$ and a linear variable displacement transducer (LVDT) was used to measure the deflection of the specimen up to failure. The value of the load and deflection at midspan $(\delta)$ were recorded continuously 


\section{EFFECT OF PALM OIL FIBER (POF) TO STRENGTH PROPERTIES}

AND FRACTURE ENERGY OF GREEN CONCRETE

Table 5: Total Number of Prism Specimens with V-Notch

\begin{tabular}{|c|c|c|}
\hline Fiber Content (\%) & Specimen ID & Number of Beam Specimen \\
\hline \multirow{3}{*}{0.00} & $0 \mathrm{~F} / \mathrm{S} 1 \mathrm{P}$ & \multirow{3}{*}{3} \\
\hline & $0 \mathrm{~F} / \mathrm{S} 2 \mathrm{P}$ & \\
\hline & 0F/S3P & \\
\hline \multirow{3}{*}{0.25} & $25 \mathrm{~F} / \mathrm{S} 1 \mathrm{P}$ & \multirow{3}{*}{3} \\
\hline & $25 \mathrm{~F} / \mathrm{S} 2 \mathrm{P}$ & \\
\hline & $25 \mathrm{~F} / \mathrm{S} 3 \mathrm{P}$ & \\
\hline \multirow{3}{*}{0.50} & $50 \mathrm{~F} / \mathrm{S} 1 \mathrm{P}$ & \multirow{3}{*}{3} \\
\hline & $50 \mathrm{~F} / \mathrm{S} 2 \mathrm{P}$ & \\
\hline & $50 \mathrm{~F} / \mathrm{S} 3 \mathrm{P}$ & \\
\hline \multirow{3}{*}{0.75} & $75 \mathrm{~F} / \mathrm{S} 1 \mathrm{P}$ & \multirow{3}{*}{3} \\
\hline & $75 \mathrm{~F} / \mathrm{S} 2 \mathrm{P}$ & \\
\hline & $75 \mathrm{~F} / \mathrm{S} 3 \mathrm{P}$ & \\
\hline \multicolumn{2}{|c|}{ TOTAL SPECIMEN } & 12 \\
\hline
\end{tabular}

\begin{tabular}{|c|c|c|c|}
\hline $50.0 \mathrm{~cm}$ & & {$[10.0 \mathrm{~cm}-]$} & \\
\hline 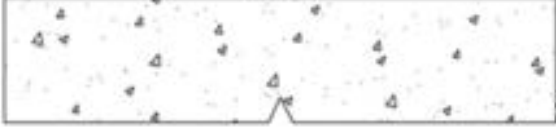 & $\begin{array}{c}10.0 \mathrm{~cm} \\
2.0 \mathrm{~cm}\end{array}$ & $\begin{array}{r}4 \\
+4\end{array}$ & $10.0 \mathrm{~cm}$ \\
\hline
\end{tabular}

Figure 2: Dimension of Prism Specimen with V-Notch

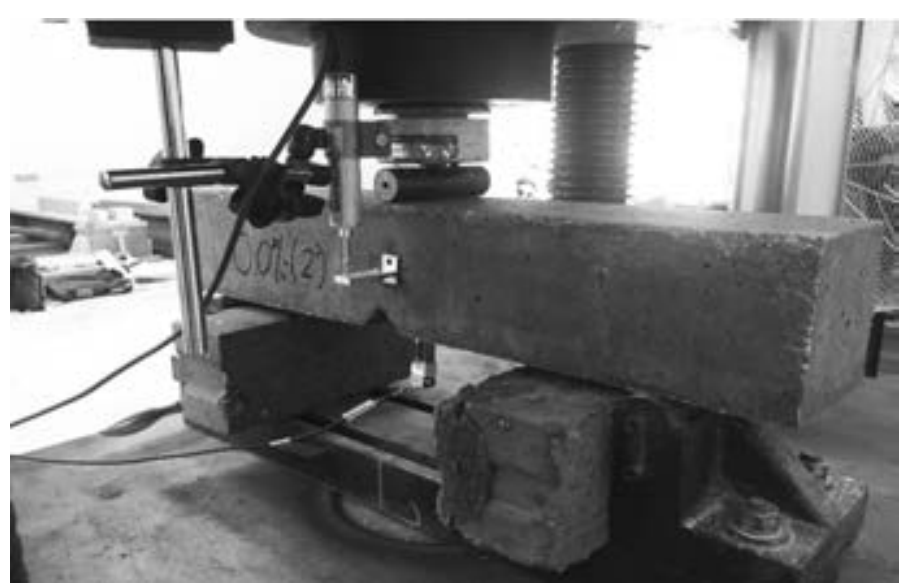

Figure 3: Three Point Bending Test

by a dedicated computer. The total number of prism specimen and its identification are shown in Table 5.

\subsection{RESULTS AND DISCUSSIONS}

\subsection{Workability}

Based on the results illustrated in Table 6, the control specimen (MC) and green concrete mix (M1, M2, M3) with several percentage of POF gave slump values ranging from $50 \mathrm{~mm}(0 \%$ $\mathrm{POF})$ to $35 \mathrm{~mm}(0.75 \% \mathrm{POF})$, which is about a $30 \%$ reduction in slump value. Therefore, it was observed that as the percentage of POF increases, the binding behaviour of POF in the concrete mix effectively reinforcing the fresh matrix, reducing its workability behaviour. However, the lower slump value observed at higher percentage of POF indicate the potential reduction of the moisture content in the green concrete mix. The trend of the slump result was the same as other green concrete with the incorporation of POF which decreases with increased POF [19].
Table 6: Slump Results

\begin{tabular}{|c|c|c|}
\hline Mixture & Slump $(\mathbf{m m})$ & Remark \\
\hline MC & 50 & $0 \%$ POF \\
\hline M1 & 42 & $0.25 \%$ POF \\
\hline M2 & 38 & $0.50 \%$ POF \\
\hline M3 & 35 & $0.75 \%$ POF \\
\hline
\end{tabular}

Note: MC-Control Specimen

\subsection{Hardened Density}

The density of hardened green concrete was measured at 7 and 28 days strength and results were tabulated in Table 7. From the results obtained, the density of green concrete shows a slight reduction from 7 days to 28 days. The highest density green concrete was measured with $0 \%$ POF while the lowest density was observed at $0.75 \%$ POF. This trend was similarly observed by the experimental work from other researchers [20] [21]. At 7 days, the addition of $0.75 \%$ of POF (M3) causes a reduction of density by $5 \%$ when compared to $0 \%$ POF (MC). Meanwhile, a reduction of nearly $4 \%$ of density was recorded at 28 days. It is also known that a normal weight concrete density lies within the specified range of $2200 \mathrm{~kg} / \mathrm{m} 3$ to $2600 \mathrm{~kg} / \mathrm{m} 3$ [21]. This also highlights the density of green concrete lies within the density of normal concrete.

Table 7: Density Development of Green Concrete at 7 Days and 28 Days

\begin{tabular}{|c|c|c|c|}
\hline \multirow{2}{*}{ Mixture } & \multicolumn{2}{|c|}{ Dry Density $\mathbf{( k g / m 3})$} & \multirow{2}{*}{ Remark } \\
\cline { 2 - 3 } & $\mathbf{7}$ days & $\mathbf{2 8}$ days & \\
\hline MC & 2244 & 2267 & $0 \%$ POF \\
\hline M1 & 2186 & 2240 & $0.25 \%$ POF \\
\hline M2 & 2160 & 2196 & $0.50 \%$ POF \\
\hline M3 & 2130 & 2180 & $0.75 \%$ POF \\
\hline
\end{tabular}

Note: $M C$ - Control specimen

\subsection{Compressive Strength Test}

Figure 4 shows the development of green concrete with different mix percentage of POF at 7 days and 28 days. From the results obtained, the compressive strength of green concrete at 28 days was higher than that of 7 days. This proved that the strength of green concrete increases during the curing period. At 7 days, concrete mix MC (0\% POF) achieved the highest compressive strength of $24.1 \mathrm{MPa}$ with concrete mix M1 $(0.25 \%$ POF) showing a slightly lower compressive strength properties at 22.0MPa. M3 (0.50\% POF) and M4 (0.75\% POF) showed lower compressive strength as illustrated in Figure 4. At 28 days strength, all concrete mix (MC, M1, M2 and M3) shows

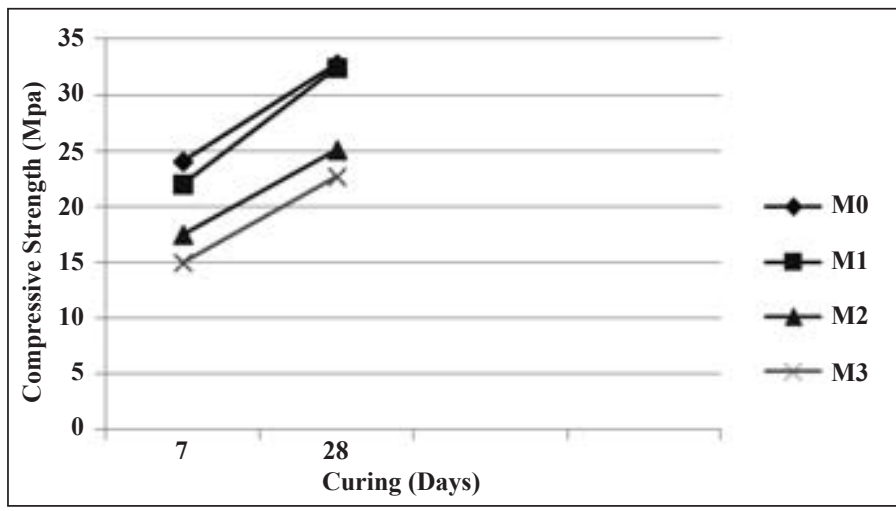

Note $: M 0=M C=0 \% P O F, M 1=0.25 \% P O F, M 2=0.50 \% P O F$, $M 3=0.75 \%$ POF

Figure 4: Compressive strength of green concrete at 7 days and 28 days 


\section{ABDUL AZIZ ABDUL SAMAD, CINDY WONG YEAN THENG, TIM EE CHING, NORIDAH MOHAMAD, MUHAMMAD AFIQ TAMBICHIK AND MOHAMAD ZULHAIRI MOHD BOSRO}

an increased in its compressive strength. However, concrete mix M1 $(0.25 \%$ POF) shows the best increment in terms of its strength as it recorded a value of $32.4 \mathrm{MPa}$, which was similar to control specimen $\mathrm{MC}(0 \% \mathrm{POF})$.

\subsection{Split Tensile Strength Test}

From observation, split tensile strength for green concrete increases steadily as the curing period increases. Generally, the highest value of split tensile strength was from control mix MC (0\% POF) as clearly illustrated in Figure 5. At 7 days, concrete mix M1 (0.25\% POF) shows the highest split tensile strength at $1.61 \mathrm{MPa}$, however, a lower tensile strength was recorded at 1.47 MPa for concrete mix M3 (0.75\% POF). As Figure 5 shows, the split tensile strength for all concrete mix (MC, M1, M2 and M3) increases upon reaching its 28 days strength. Nevertheless, the presence of POF in the concrete mix shows a definite influence to the split tensile strength similar to the reduction of its compressive strength as presented in Section 6.3 above. At 28 days, the concrete mix MC ( $0 \%$ POF), M1 (0.25\% POF), M2 $(0.50 \%$ POF) and M3 (0.75\% POF) shows an increasing trend from its 7 days strength but reduces with increased percentage of POF from 2.50 MPa, 2.30 MPa, 2.20MPa and 1.80 MPa respectively.

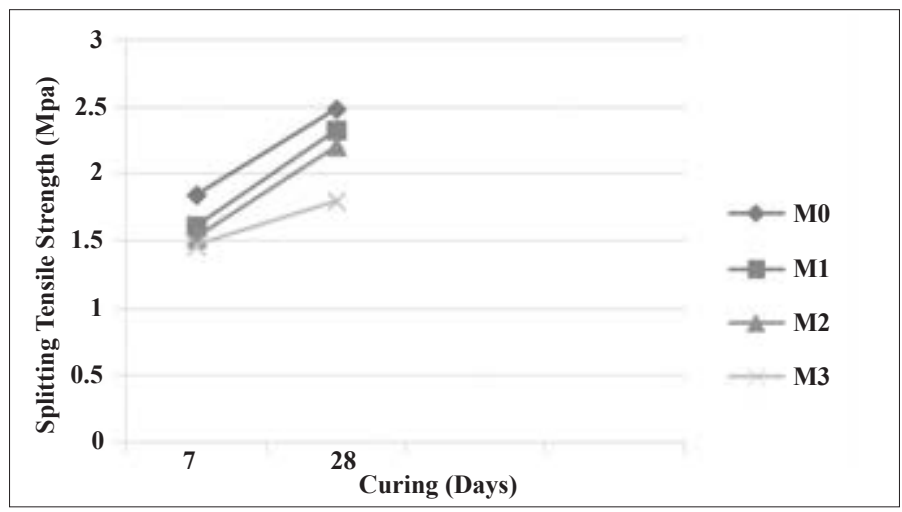

Note: $M O=M C=0 \%$ POF, $M 1=0.25 \%$ POF, $M 2=0.50 \% P O F$,

$$
M 3=0.75 \% \text { POF }
$$

Figure 5: Splitting Tensile Strength of Green Concrete at 7 Days and 28 Days

\subsection{Failure Mode}

After the compression and split tensile strength test, all the cubes and cylinders shows a consistent failure mode with little damage. Equally distributed cracks on the surface of the cube specimens were also observed. Typical failure modes for the cubes and cylinders are shown clearly in Table 8 and Table 9 for concrete mix MC (0\% POF) and M1 (0.25\% POF). Overall, the green concrete cubes and cylinders have shown good failure criteria whilst achieving the targeted design strength of $30 \mathrm{MPa}$.

Table 8: Failure Modes of Green Concrete After Compressive Test

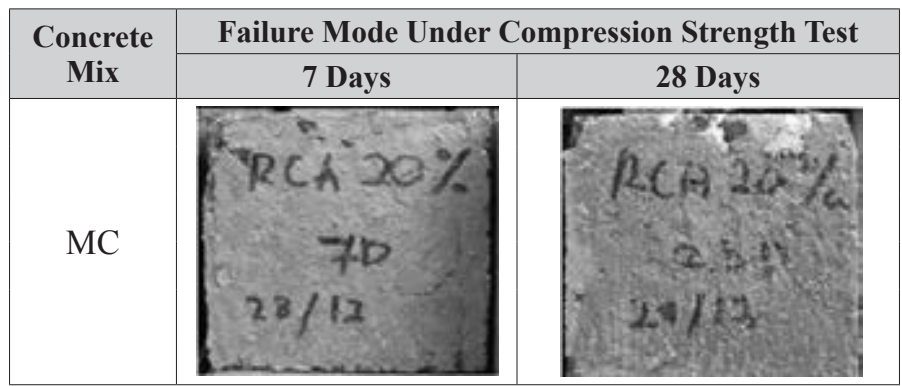

Note: $\mathrm{MC}=$ Control specimen $(0 \% \mathrm{POF}) ; \mathrm{M1}=0.25 \% \mathrm{POF}$
Table 8: Failure Modes of Green Concrete After Compressive Test

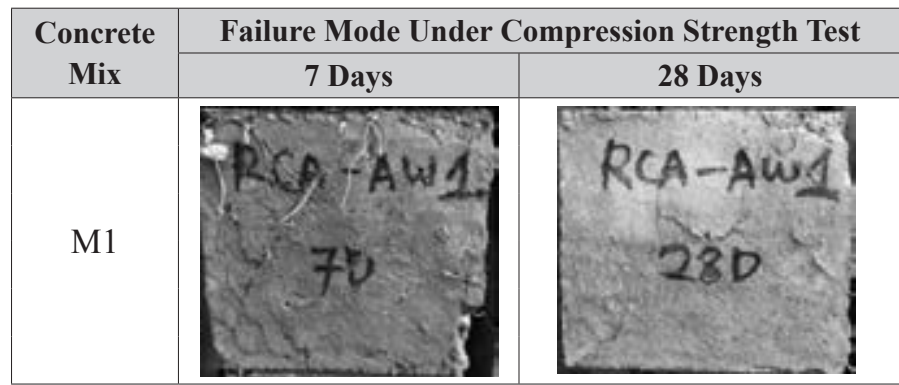

Note: $\mathrm{MC}=$ Control specimen $(0 \% \mathrm{POF}) ; \mathrm{M1}=0.25 \% \mathrm{POF}$

Table 9: Failure Modes of Green Concrete After Splitting Tensile Test

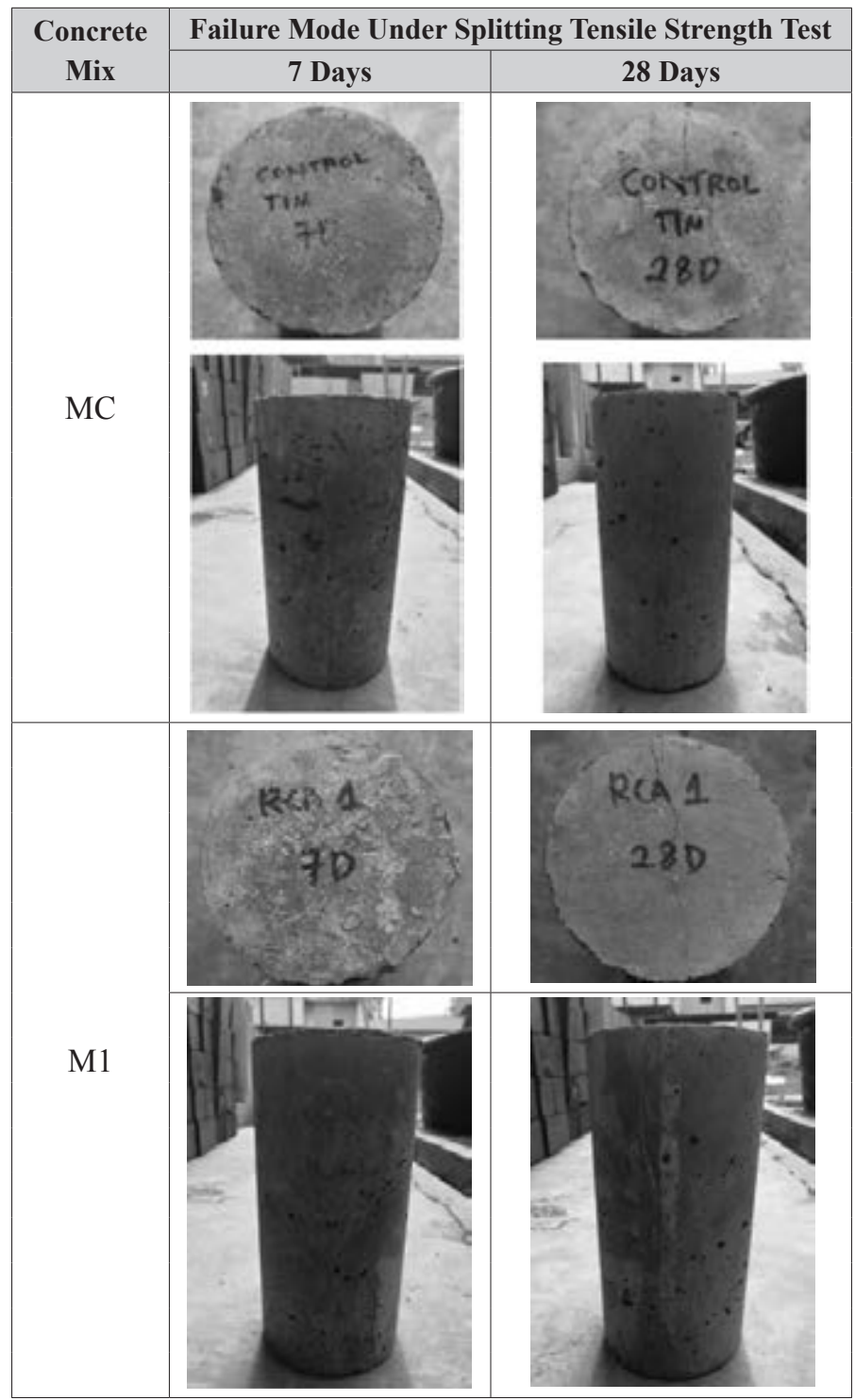

Note: $\mathrm{MC}=$ Control Specimen $(0 \% \mathrm{POF}) ; \mathrm{M1}=0.25 \% \mathrm{POF}$

\subsection{Failure Mode}

From close observation, the crack pattern for all specimens are similar, where cracks occurred at the mid-span of specimen, see Table 10. The formation of cracks were observed at the notched region where high stresses are expected at the narrow end of the v-notch. The cracks propagated from the tip of the notch to the upper surface of the beam. It can be seen that the cracks in all specimens are approximately vertical in direction with very slight changes in its angle. 


\section{EFFECT OF PALM OIL FIBER (POF) TO STRENGTH PROPERTIES AND FRACTURE ENERGY OF GREEN CONCRETE}

Table 10: Failure Mode of Specimen

\begin{tabular}{|c|c|}
\hline $\begin{array}{l}\text { Specimen } \\
\text { ID }\end{array}$ & Crack Pattern and Deflection at Failure \\
\hline \multirow[t]{2}{*}{ 0F/S2P } & \\
\hline & Deflection at failure: $0.29 \mathrm{~mm}$ \\
\hline \multirow[t]{2}{*}{$25 \mathrm{~F} / \mathrm{S} 2 \mathrm{P}$} & \\
\hline & Deflection at failure: $0.32 \mathrm{~mm}$ \\
\hline \multirow[t]{2}{*}{$50 \mathrm{~F} / \mathrm{S} 2 \mathrm{P}$} & \\
\hline & Deflection at failure: $0.34 \mathrm{~mm}$ \\
\hline \multirow[t]{2}{*}{$75 \mathrm{~F} / \mathrm{S} 2 \mathrm{P}$} & \\
\hline & Deflection at failure: $0.47 \mathrm{~mm}$ \\
\hline
\end{tabular}

\subsection{Load-deflection Profile}

All notched prism specimens in various fiber percentage of $0.00 \%, 0.25 \%, 0.50 \%$ and $0.75 \%$ are tested with three point bending test. All specimens are cast with constant size of $100 \mathrm{~mm}$ x $100 \mathrm{~mm}$ x $500 \mathrm{~mm}$ and a notch with depth of $20 \mathrm{~mm}$ at midspan. The specimens are loaded at centre until it experiences crack and fracture.

The data obtained from three point bending test are recorded and analysed to produce load-deflection profile. The loaddeflection profile at peak load, displacement at peak load and load and displacement at failure is summarized in Table 11. The load-deflection profile for each specimen was plotted to compute the area under the profile. The area under load-deflection profile were then used to calculate the fracture energy of green concrete in accordance to Hillerborg's model [10].

\section{Table 11: Load and Deflection of Peak Load and Failure Load}

\begin{tabular}{|c|c|c|c|c|c|}
\hline \multirow[b]{2}{*}{$\begin{array}{c}\text { Fiber } \\
\text { content } \\
(\%)\end{array}$} & \multirow[b]{2}{*}{$\begin{array}{c}\text { Specimen } \\
\text { ID }\end{array}$} & \multicolumn{4}{|c|}{ Experimental Results } \\
\hline & & $\begin{array}{c}\text { Peak load } \\
(k N)\end{array}$ & $\begin{array}{c}\text { Deflection } \\
\text { at peak } \\
\text { load }(\mathrm{mm})\end{array}$ & $\begin{array}{c}\text { Load at } \\
\text { failure } \\
(\mathrm{kN})\end{array}$ & $\begin{array}{c}\text { Deflection } \\
\text { at failure } \\
(\mathrm{mm})\end{array}$ \\
\hline \multirow{3}{*}{0.00} & $0 \mathrm{~F} / \mathrm{S} 1 \mathrm{P}$ & - & - & - & - \\
\hline & $0 \mathrm{~F} / \mathrm{S} 2 \mathrm{P}$ & 7.62 & 0.27 & 0.08 & 0.29 \\
\hline & 0F/S3P & 7.30 & 0.25 & 0.10 & 0.30 \\
\hline \multirow{3}{*}{0.25} & $25 \mathrm{~F} / \mathrm{S} 1 \mathrm{P}$ & 7.16 & 0.21 & 0.16 & 0.27 \\
\hline & $25 \mathrm{~F} / \mathrm{S} 2 \mathrm{P}$ & 7.37 & 0.20 & 0.20 & 0.32 \\
\hline & $25 \mathrm{~F} / \mathrm{S} 3 \mathrm{P}$ & 6.96 & 0.25 & 0.19 & 0.35 \\
\hline \multirow{3}{*}{0.50} & $50 \mathrm{~F} / \mathrm{S} 1 \mathrm{P}$ & 7.00 & 0.17 & 0.30 & 0.36 \\
\hline & $50 \mathrm{~F} / \mathrm{S} 2 \mathrm{P}$ & 6.52 & 0.18 & 0.29 & 0.34 \\
\hline & $50 \mathrm{~F} / \mathrm{S} 3 \mathrm{P}$ & 7.68 & 0.18 & 0.24 & 0.38 \\
\hline \multirow{3}{*}{0.75} & $75 \mathrm{~F} / \mathrm{S} 1 \mathrm{P}$ & 6.67 & 0.23 & 0.24 & 0.46 \\
\hline & $75 \mathrm{~F} / \mathrm{S} 2 \mathrm{P}$ & 6.14 & 0.22 & 0.28 & 0.47 \\
\hline & $75 \mathrm{~F} / \mathrm{S} 3 \mathrm{P}$ & 6.22 & 0.18 & 0.30 & 0.42 \\
\hline
\end{tabular}

The load-deflection profile for $0 \mathrm{~F} / \mathrm{S} 2 \mathrm{P}$ (see Figure 6) shows that the deflection increase simultaneously with the increasing applied load until it reaches peak load of $7.62 \mathrm{kN}$. The maximum deflection at peak load is recorded at $0.27 \mathrm{~mm}$. After reaching the peak load, it is observed that the load decrease sharply with slight increase in deflection. The overall load-deflection profile for $0 \mathrm{~F} / \mathrm{S} 3 \mathrm{P}$ shows similar trend with $0 \mathrm{~F} / \mathrm{S} 2 \mathrm{P}$. However, it was found smaller peak load and lower deflection at peak load with value of $7.30 \mathrm{kN}$ and $0.25 \mathrm{~mm}$ are recorded for $0 \mathrm{~F} / \mathrm{S} 3 \mathrm{P}$.

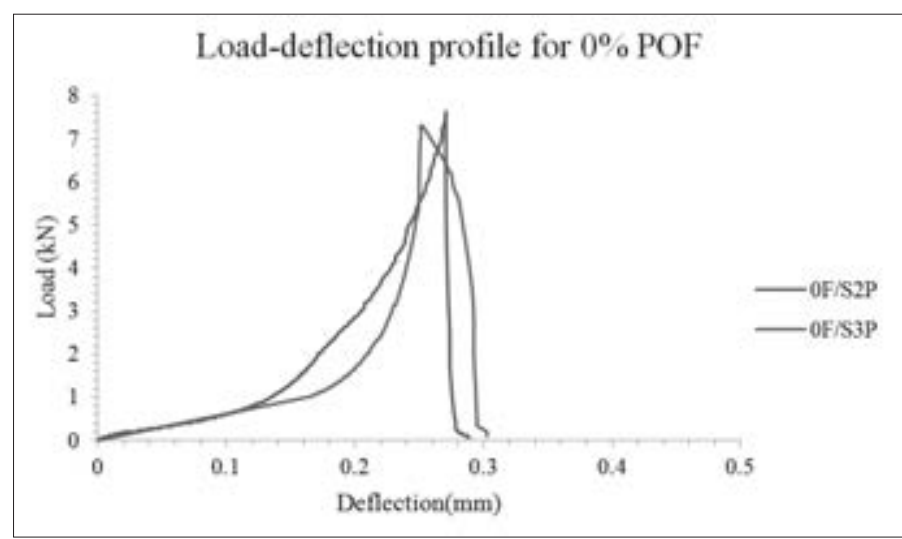

Figure 6: Load-deflection Profile for 0\% POF

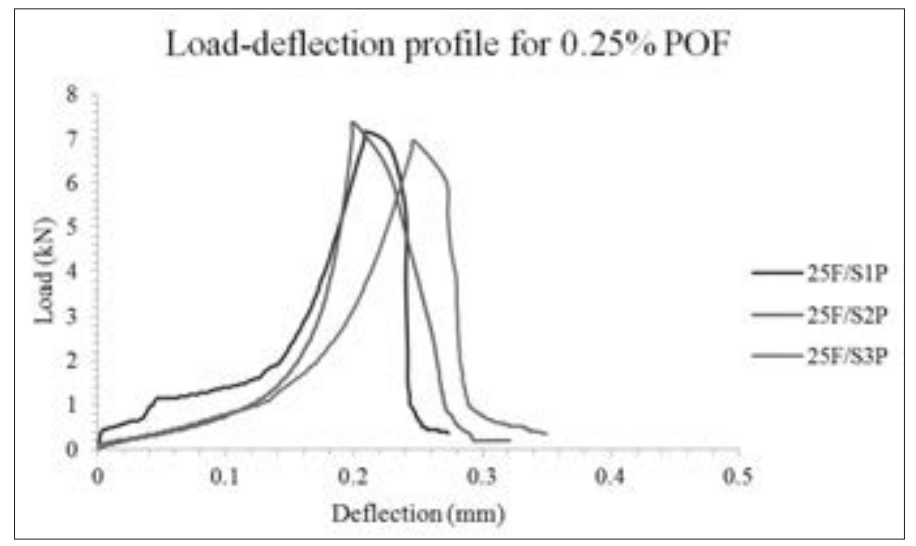

Figure 7: Load-deflection Profile for 0.25\% POF

Figure 7 clearly shows the load-deflection profile for green concrete with $0.25 \%$ POF. From Figure 7 , it is observed that the profile for $25 \mathrm{~F} / \mathrm{S} 1 \mathrm{P}$ is similar with load-deflection profile for $0 \mathrm{~F} / \mathrm{S} 3$. This profile trend is similarly observed for $25 \mathrm{~F} / \mathrm{S} 2 \mathrm{P}$ and $25 \mathrm{~F} / \mathrm{S} 3 \mathrm{P}$. A peak load value of $7.16 \mathrm{kN}, 7.37 \mathrm{kN}$ and $6.96 \mathrm{kN}$ with deflection of $0.21 \mathrm{~mm}, 0.20 \mathrm{~mm}$ and $0.25 \mathrm{~mm}$ are recorded for $25 \mathrm{~F} /$ S1P, 25F/S2P and 25F/S3P respectively. As illustrated in Figure 7 , the load capacity for all specimen decreased sharply after peak load is achieved. This decrease in load capacity coincides with a slight increase in deflection value.

The load-deflection profile for specimen 50F/S1P shows gradual increase in deflection with an increase in load. At peak load, specimen $50 \mathrm{~F} / \mathrm{S} 1 \mathrm{P}$ recorded a load value of $7.00 \mathrm{kN}$ with a deflection at $0.17 \mathrm{~mm}$. The same trend is observed for $50 \mathrm{~F} / \mathrm{S} 2 \mathrm{P}$ and $50 \mathrm{~F} / \mathrm{S} 3 \mathrm{P}$ in Figure 8 . A peak load of $6.52 \mathrm{kN}$ and $7.68 \mathrm{kN}$ with deflection of $0.18 \mathrm{~mm}$ and $0.18 \mathrm{~mm}$ are recorded for $50 \mathrm{~F} /$ $\mathrm{S} 2 \mathrm{P}$ and $50 \mathrm{~F} / \mathrm{S} 3 \mathrm{P}$ respectively. All specimen show a gradual decrease in load after peak load is reached. This gradual decrease in load coincides with an increase in deflection. When maximum deflection of 50F/S1P reaches $0.36 \mathrm{~mm}$, the final load was recorded at $0.30 \mathrm{kN}$. The post-peak behavior for $50 \mathrm{~F} / \mathrm{S} 2 \mathrm{P}$ and $50 \mathrm{~F} / \mathrm{S} 3 \mathrm{P}$ show a similar trend with a gradual reduction in its load capacity recorded at $0.29 \mathrm{kN}$ and $0.24 \mathrm{kN}$ and a maximum deflection at $0.34 \mathrm{~mm}$ and $0.38 \mathrm{~mm}$ respectively. 


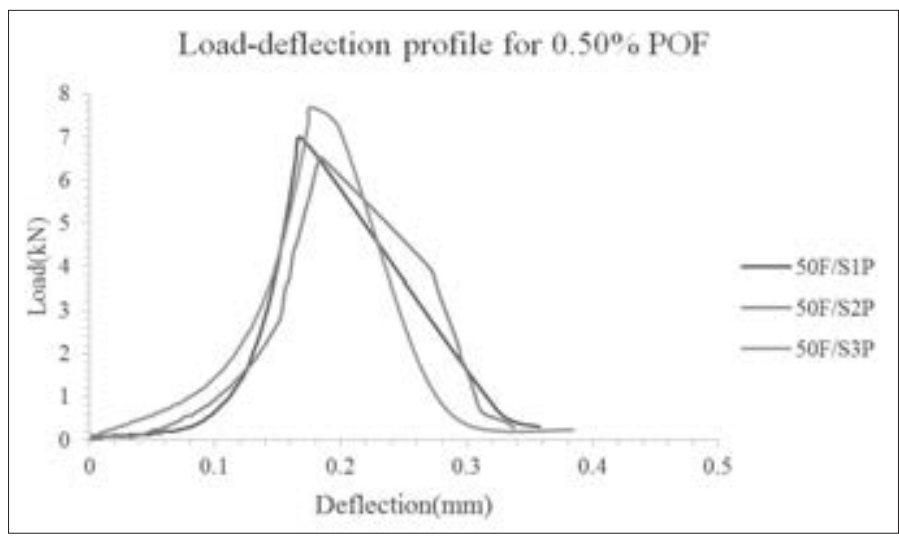

Figure 8: Load-deflection Profile for 0.50\% POF

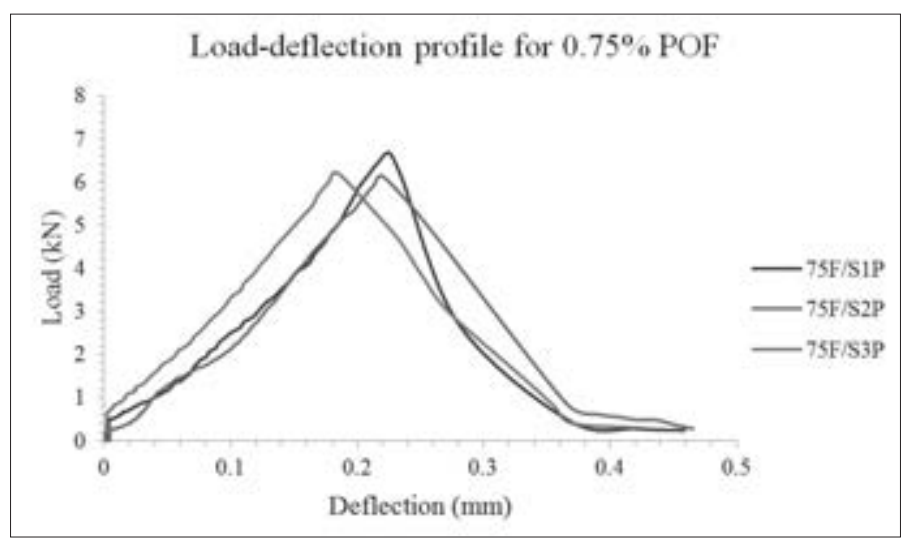

Figure 9: Load-deflection Profile for 0.75\% POF

Figure 9 shows the load-deflection profile for green concrete with $0.75 \%$ POF until failure. It is observed that the initial behavior of specimens under load show no significant increase in deflection. The load is then increase linearly with deflection until reaching peak load. The post peak behavior of all specimen show gradual decrease until failure. A peak load value of $6.67 \mathrm{kN}, 6.14 \mathrm{kN}$ and $6.22 \mathrm{kN}$ with deflection of $0.23 \mathrm{~mm}, 0.22 \mathrm{~mm}$ and $0.18 \mathrm{~mm}$ are recorded for $75 \mathrm{~F} / \mathrm{S} 1 \mathrm{P}, 75 \mathrm{~F} / \mathrm{S} 2 \mathrm{P}$ and $75 \mathrm{~F} / \mathrm{S} 3 \mathrm{P}$ respectively.

Load-deflection profile for specimen $0 \mathrm{~F} / \mathrm{S} 2 \mathrm{P}, 25 \mathrm{~F} / \mathrm{S} 2 \mathrm{P}$, $50 \mathrm{~F} / \mathrm{S} 2 \mathrm{P}$ and $75 \mathrm{~F} / \mathrm{S} 2 \mathrm{P}$ is visualized in Figure 10 to illustrate the influence of POF to the peak load and maximum deflection of green concrete. Peak load of $7.62 \mathrm{kN}, 7.37 \mathrm{kN}, 6.52 \mathrm{kN}$ and $6.14 \mathrm{kN}$ with maximum deflection of $0.30 \mathrm{~mm}, 0.32 \mathrm{~mm}, 0.34 \mathrm{~mm}$ and $0.47 \mathrm{~mm}$ are recorded for $0 \mathrm{~F} / \mathrm{S} 2 \mathrm{P}, 25 \mathrm{~F} / \mathrm{S} 2 \mathrm{P}, 50 \mathrm{~F} / \mathrm{S} 2 \mathrm{P}$ and $75 \mathrm{~F} /$ $\mathrm{S} 2 \mathrm{P}$ respectively. It is clearly seen that the peak load of specimen is decreasing with increasing POF percentage. However, higher percentage of POF improves the ductility behaviour as show in figure 10 .

\subsection{FRACTURE ENERGY}

The fracture energy $G_{F}$ of green concrete prims is analysed using three models, namely Hillerborg's model 10], Bazant model [11] and Comite Euro-International du Beton (CEB) model [12].

\subsection{Hillerborg's Model [10]}

The analysis using Hillerborg's model depends on the experimental result obtained from three point bending test. The area under load-deflection profile for each specimen will greatly influence the value of fracture energy. The fracture energy of

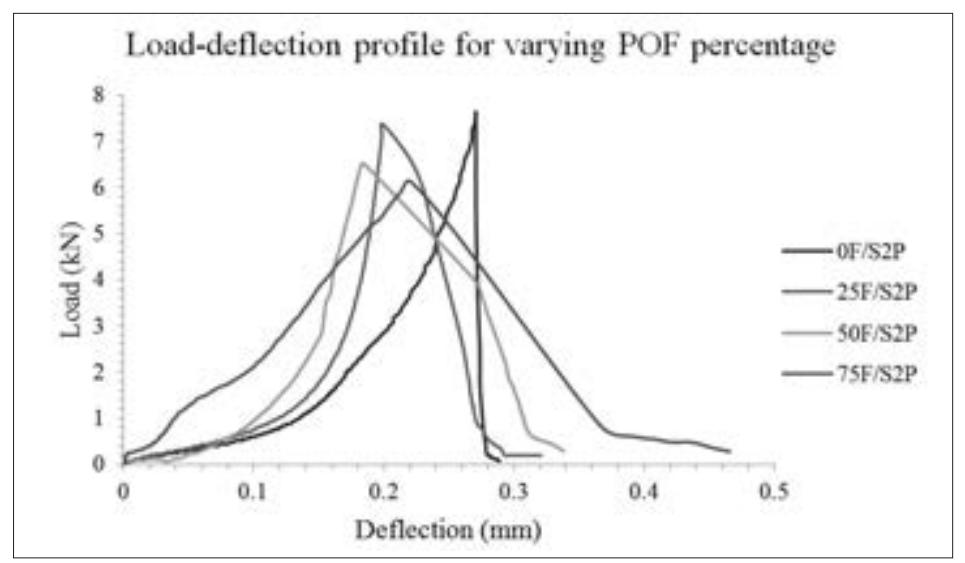

Figure 10: Load-deflection Profile for Varying POF Percentage

Table 12: Fracture Energy of Green Concrete Based on Hillerborg's Model [10]

\begin{tabular}{|c|c|c|c|c|c|c|c|c|}
\hline $\begin{array}{c}\text { Fiber } \\
\text { content } \\
(\mathbf{\%})\end{array}$ & $\begin{array}{c}\text { Specimen } \\
\text { ID }\end{array}$ & $\begin{array}{c}\boldsymbol{W}_{\boldsymbol{o}} \\
(\mathbf{N} . \mathbf{m})\end{array}$ & $\begin{array}{c}\boldsymbol{m}_{\boldsymbol{g}} \\
(\mathbf{N})\end{array}$ & $\boldsymbol{\delta}_{\boldsymbol{f}}(\mathbf{m})$ & $\begin{array}{c}\boldsymbol{B} \\
(\mathbf{m})\end{array}$ & $\begin{array}{c}\boldsymbol{D} \\
(\mathbf{m})\end{array}$ & $\begin{array}{c}\boldsymbol{a}_{\boldsymbol{o}} \\
(\mathbf{m})\end{array}$ & $\begin{array}{c}\boldsymbol{G}_{\boldsymbol{F}} \\
(\mathbf{N} / \mathbf{m})\end{array}$ \\
\hline \multirow{3}{*}{0.00} & $0 \mathrm{~F} / \mathrm{S} 1 \mathrm{P}$ & - & - & - & 0.1 & 0.1 & 0.02 & - \\
\cline { 2 - 9 } & $0 \mathrm{~F} / \mathrm{S} 2 \mathrm{P}$ & 0.53 & 118.11 & 0.0003 & 0.1 & 0.1 & 0.02 & 70.39 \\
\cline { 2 - 9 } & $0 \mathrm{~F} / \mathrm{S} 3 \mathrm{P}$ & 0.54 & 118.11 & 0.0003 & 0.1 & 0.1 & 0.02 & 71.68 \\
\hline \multirow{3}{*}{0.25} & $25 \mathrm{~F} / \mathrm{S} 1 \mathrm{P}$ & 0.67 & 112.82 & 0.0003 & 0.1 & 0.1 & 0.02 & 87.54 \\
\cline { 2 - 10 } & $25 \mathrm{~F} / \mathrm{S} 2 \mathrm{P}$ & 0.65 & 112.42 & 0.0003 & 0.1 & 0.1 & 0.02 & 85.52 \\
\cline { 2 - 10 } & $25 \mathrm{~F} / \mathrm{S} 3 \mathrm{P}$ & 0.69 & 112.23 & 0.0003 & 0.1 & 0.1 & 0.02 & 90.50 \\
\hline \multirow{3}{*}{0.50} & $50 \mathrm{~F} / \mathrm{S} 1 \mathrm{P}$ & 0.86 & 118.31 & 0.0004 & 0.1 & 0.1 & 0.02 & 112.44 \\
\cline { 2 - 9 } & $50 \mathrm{~F} / \mathrm{S} 2 \mathrm{P}$ & 0.84 & 117.72 & 0.0003 & 0.1 & 0.1 & 0.02 & 110.12 \\
\cline { 2 - 9 } & $50 \mathrm{~F} / \mathrm{S} 3 \mathrm{P}$ & 0.86 & 117.72 & 0.0004 & 0.1 & 0.1 & 0.02 & 113.10 \\
\hline \multirow{3}{*}{0.75} & $75 \mathrm{~F} / \mathrm{S} 1 \mathrm{P}$ & 1.10 & 118.50 & 0.0005 & 0.1 & 0.1 & 0.02 & 144.22 \\
\cline { 2 - 9 } & $75 \mathrm{~F} / \mathrm{S} 2 \mathrm{P}$ & 1.19 & 116.05 & 0.0005 & 0.1 & 0.1 & 0.02 & 154.88 \\
\cline { 2 - 9 } & $75 \mathrm{~F} / \mathrm{S} 3 \mathrm{P}$ & 1.18 & 115.07 & 0.0004 & 0.1 & 0.1 & 0.02 & 153.81 \\
\hline
\end{tabular}

green concrete analysed using Hillerborg's model is obtained from figure 10 above and summarised in Table 12.

The fracture energy values $G_{F}$ tabulated in Table 12 are calculated using the fracture energy equation based on Hillerborg's model as shown in Equation.1. It was observed that the inclusion of POF in green concrete shows positive effect on the fracture energy. The fracture energy from specimen with higher POF content show better results where the fracture energy increased from $70.39 \mathrm{~N} / \mathrm{m}$ to $153.81 \mathrm{~N} / \mathrm{m}$ when POF content increased from $0 \%$ to $0.75 \%$. The increasing influence of POF to fracture energy of green concrete in Hillerborg's model are illustrated in Figure 11 below.

\subsection{Bazant [11] and CEB [12] Model}

Fracture energy of green concrete were also analysed using Bazant and $\mathrm{CEB}$ models which was shown as Equation 2 and Equation

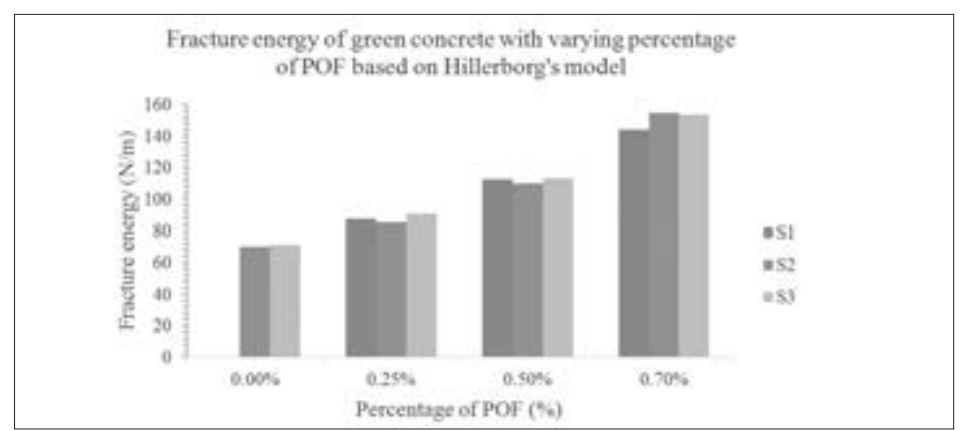

Figure 11: Fracture Energy of Green Concrete with Varying Percentage of POF Based on Hillerborg's Model [10] 


\section{EFFECT OF PALM OIL FIBER (POF) TO STRENGTH PROPERTIES AND FRACTURE ENERGY OF GREEN CONCRETE}

3 above. Bazant and CEB models employs the cylindrical compressive strength, maximum size of aggregate, watercement ratio in determining its fracture energy of green concrete. The value of fracture energy analysed using these models are tabulated in Table 13 and Table 14 respectively.

Based on the values shown in Table 13 and Table 14, the fracture energy obtained for green concrete without adding POF was the highest followed by specimen with $0.25 \%, 0.50 \%$ and $0.75 \%$ POF. The fracture energy was found to decrease with increasing fiber content. This observation was contributed mainly due to the presence of compressive strength of concrete from Bazant and CEB models whilst the parameter for the maximum size of aggregate and water-cement ratio remains constant. The cylindrical compressive strength of green concrete without fiber was the highest at $26.27 \mathrm{MPa}$ compared to $0.25 \%$, $0.50 \%$ and $0.75 \%$ POF with a compressive strength of 25.92 $\mathrm{MPa}, 20.11 \mathrm{MPa}$ and 18.21 MPa respectively. This shows that the compressive strength of specimen will affect the value of fracture energy from Bazant and CEB model.

The distribution of fracture energy from Bazant and CEB model with varying percentage of POF are illustrated in Figure

Table 13: Fracture Energy of Green Concrete Based on Bazant Model [11]

\begin{tabular}{|c|c|c|c|c|c|c|}
\hline $\begin{array}{c}\text { Fiber } \\
\text { content } \\
(\mathbf{\%})\end{array}$ & $\begin{array}{c}\text { Specimen } \\
\text { ID }\end{array}$ & $\boldsymbol{\alpha}_{\boldsymbol{o}}$ & $\begin{array}{c}\mathbf{D}_{\max } \\
(\mathbf{m m})\end{array}$ & $\begin{array}{c}\boldsymbol{f}_{\boldsymbol{c}} \\
(\mathbf{M P a})\end{array}$ & $\begin{array}{c}\boldsymbol{W} \\
\boldsymbol{C}\end{array}$ & $\begin{array}{c}\boldsymbol{G}_{\boldsymbol{F}} \\
(\mathrm{N} / \mathrm{m})\end{array}$ \\
\hline \multirow{3}{*}{0.00} & $0 \mathrm{~F} / \mathrm{S} 1 \mathrm{C}$ & 1.44 & 9 & 25.76 & 0.57 & 96.00 \\
\cline { 2 - 7 } & $0 \mathrm{~F} / \mathrm{S} 2 \mathrm{C}$ & 1.44 & 9 & 26.32 & 0.57 & 85.80 \\
\cline { 2 - 7 } & $0 \mathrm{~F} / \mathrm{S} 3 \mathrm{C}$ & 1.44 & 9 & 26.72 & 0.57 & 86.39 \\
\hline \multirow{3}{*}{0.25} & $25 \mathrm{~F} / \mathrm{S} 1 \mathrm{C}$ & 1.44 & 9 & 25.2 & 0.57 & 84.10 \\
\cline { 2 - 7 } & $25 \mathrm{~F} / \mathrm{S} 2 \mathrm{C}$ & 1.44 & 9 & 27.6 & 0.57 & 87.69 \\
\cline { 2 - 7 } & $25 \mathrm{~F} / \mathrm{S} 3 \mathrm{C}$ & 1.44 & 9 & 24.96 & 0.57 & 83.73 \\
\hline \multirow{3}{*}{0.50} & $50 \mathrm{~F} / \mathrm{S} 1 \mathrm{C}$ & 1.44 & 9 & 20.72 & 0.57 & 76.86 \\
\cline { 2 - 7 } & $50 \mathrm{~F} / \mathrm{S} 2 \mathrm{C}$ & 1.44 & 9 & 19.12 & 0.57 & 74.07 \\
\cline { 2 - 7 } & $50 \mathrm{~F} / \mathrm{S} 3 \mathrm{C}$ & 1.44 & 9 & 20.48 & 0.57 & 76.45 \\
\hline \multirow{3}{*}{0.75} & $75 \mathrm{~F} / \mathrm{S} 1 \mathrm{C}$ & 1.44 & 9 & 17.84 & 0.57 & 71.74 \\
\cline { 2 - 7 } & $75 \mathrm{~F} / \mathrm{S} 2 \mathrm{C}$ & 1.44 & 9 & 18.64 & 0.57 & 73.21 \\
\cline { 2 - 7 } & $75 \mathrm{~F} / \mathrm{S} 3 \mathrm{C}$ & 1.44 & 9 & 18.16 & 0.57 & 72.33 \\
\hline
\end{tabular}

Table 14: Fracture Energy of Green Concrete Based on CEB Model [12]

\begin{tabular}{|c|c|c|c|c|}
\hline Fiber content (\%) & Specimen ID & $\begin{array}{c}\boldsymbol{D}_{\max } \\
(\mathbf{m m})\end{array}$ & $\begin{array}{c}\boldsymbol{f}_{\boldsymbol{c}} \\
(\mathbf{M P a})\end{array}$ & $\begin{array}{c}\boldsymbol{G}_{\boldsymbol{F}} \\
(\mathbf{N} / \mathbf{m})\end{array}$ \\
\hline \multirow{3}{*}{0.00} & $0 \mathrm{~F} / \mathrm{S} 1 \mathrm{C}$ & 9 & 25.76 & 49.06 \\
\cline { 2 - 5 } & $0 \mathrm{~F} / \mathrm{S} 2 \mathrm{C}$ & 9 & 26.32 & 49.81 \\
\cline { 2 - 5 } & $0 \mathrm{~F} / \mathrm{S} 3 \mathrm{C}$ & 9 & 26.72 & 50.34 \\
\hline \multirow{3}{*}{0.25} & $25 \mathrm{~F} / \mathrm{S} 1 \mathrm{C}$ & 9 & 25.2 & 48.32 \\
\cline { 2 - 5 } & $25 \mathrm{~F} / \mathrm{S} 2 \mathrm{C}$ & 9 & 27.6 & 51.49 \\
\cline { 2 - 5 } & $25 \mathrm{~F} / \mathrm{S} 3 \mathrm{C}$ & 9 & 24.96 & 47.99 \\
\hline \multirow{3}{*}{0.50} & $50 \mathrm{~F} / \mathrm{S} 1 \mathrm{C}$ & 9 & 20.72 & 42.13 \\
\cline { 2 - 5 } & $50 \mathrm{~F} / \mathrm{S} 2 \mathrm{C}$ & 9 & 19.12 & 39.82 \\
\cline { 2 - 5 } & $50 \mathrm{~F} / \mathrm{S} 3 \mathrm{C}$ & 9 & 20.48 & 41.79 \\
\hline \multirow{3}{*}{0.75} & $75 \mathrm{~F} / \mathrm{S} 1 \mathrm{C}$ & 9 & 17.84 & 37.94 \\
\cline { 2 - 5 } & $75 \mathrm{~F} / \mathrm{S} 2 \mathrm{C}$ & 9 & 18.64 & 39.12 \\
\cline { 2 - 5 } & $75 \mathrm{~F} / \mathrm{S} 3 \mathrm{C}$ & 9 & 18.16 & 38.41 \\
\hline
\end{tabular}

12 and Figure 13 respectively. The figures below shows that the fracture energy of green concrete decreases with increasing fiber content for both models.

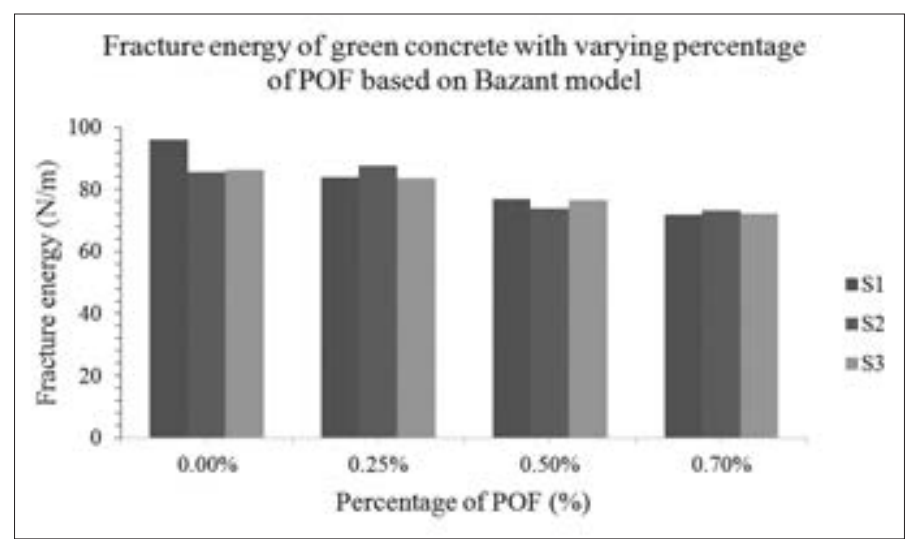

Figure 12: Fracture Energy of Green Concrete with Varying Percentage of POF Based on Bazant Model [11]

Fracture energy of green concrete with varying percentage of POF based on CEB model

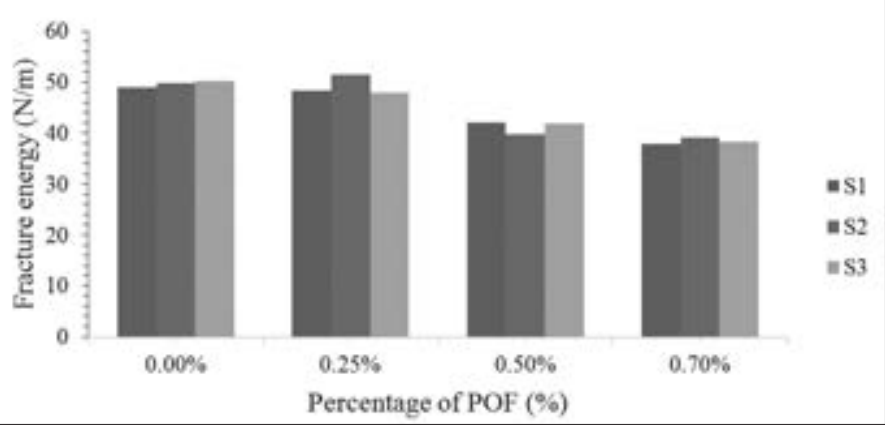

Figure 13: Fracture Energy of Green Concrete with Varying Percentage of POF Based on CEB Model [12]

\subsection{CONCLUSION}

Throughout the research, it was noted that the agricultural waste materials used in the mixture of green concrete possess an excellent potential to enhance the strength properties of green concrete. As proven from the results, the concrete mix $\mathrm{MC}$ without the addition of POF achieved the value higher than the targeted design strength of $30 \mathrm{MPa}$. However, the concrete mix M1 of $0.25 \%$ POF also presented satisfactory results as the strength development on 28 days was $32.4 \mathrm{MPa}$. Therefore, the mixture of all the material proposed can definitely be used to create green concrete to mitigate the global warming by reducing a significant amount of carbon dioxide from the use of cement.

Fracture energy for green concrete with varying percentage of POF was also determined. Fracture energy of green concrete with varying percentage of palm oil fiber was found to be in the range of $37.94 \mathrm{~N} / \mathrm{m}$ to $150.97 \mathrm{~N} / \mathrm{m}$. The result of three-point bending test shows that $0.75 \%$ inclusion of palm oil fiber gives the highest fracture energy but lowest compressive strength. The fracture energy of green concrete calculated using Bazant and CEB models are lower than fracture energy analyzed using Hillerborg model. This is due to the fracture energy value according to Bazant and CEB modes highly depend on compressive strength compared to Hillerborg model which rely on the area under the load-deflection profile. Finally, this research has successfully achieved its aims in determining the strength 


\section{ABDUL AZIZ ABDUL SAMAD, CINDY WONG YEAN THENG, TIM EE CHING, NORIDAH MOHAMAD, MUHAMMAD AFIQ TAMBICHIK AND MOHAMAD ZULHAIRI MOHD BOSRO}

properties and fracture energy of green concrete utilizing waste materials from POFA, RHA, POF and RCA.

\section{ACKNOWLEDGEMENT}

The authors expresses their gratitude to the Ministry of Higher Education, Malaysia for funding this research under the Fundamental Research Grant Scheme (FRGS) VOT No. 1573.

\section{REFERENCES}

[1] E. Aprianti, P. Shafigh, S. Bahri, and J. Nodeh, "Supplementary cementitious materials origin from agricultural wastes - A review," Construction and Building Materials, vol. 74, pp. 176$187,2015$.

[2] B. Skariah, S. Kumar, and H. Sahan, "Sustainable concrete containing palm oil fuel ash as a supplementary cementitious material - A review," Renew. Sustain. Energy Rev., vol. 80, no. May, pp. 550-561, 2017.

[3] H. Chao-Lung, B. Le Anh-Tuan, and C. Chun-Tsun, "Effect of rice husk ash on the strength and durability characteristics of concrete," Construction and Building Materials, vol. 25, no. 9, pp. 3768-3772, 2011.

[4] R.K. Sandhu and R. Siddique, "Influence of rice husk ash (RHA) on the proerties of self-compacting concrete: A review", Construction and Building Materials, vol. 153, pp. 751-764, October 2017

[5] J. García-González et al., "Fracture energy of coarse recycled aggregate concrete using the wedge splitting test method: influence of water-reducing admixtures", Mater. Struct., vol. 50, pp. 1-15, 2017.

[6] M. A. Ismail and H. B. Hashim, "Palm oil fiber concrete", The 3rd Asian Concrete Federation International Conference, Ho Chi Minh, Vietnam, 11-13 November, 2008

[7] P. Amuthakkannan, V. Manikandan, J. T. W. Jappes, and M. Uthayakumar, "Effect of Fibre Length and Fibre Content on Mechanical Properties of Short Basalt Fibre," Mater. Phys. Mech., vol. 16, pp. 107-117, 2013.
[8] M. H. Ahmad and N. Mohd Noor, "Mix Design of Palm Oil Fiber Concrete", International Conference on Civil Engineering (ICCE08), May 2008.

[9] N. Abd Rahman and Z. Mohd Jaini, "Effect of Span-to-Depth Ratio on the Fracture Energy of Foam Concrete," Key Engineering Materials, vol. 730, no. March, pp. 440-444, 2017.

[10] A. Hillerborg, "The theoretical basis of a method to determine the fracture energy GF of concrete," Mater. Struct., vol. 18, no. 4, pp. 291-296, 1985.

[11] Z. P. Bažant, "Concrete fracture models: Testing and practice," Eng. Fract. Mech., vol. 69, no. 2, pp. 165-205, 2001.

[12] Comite Euro-International du Beton, "Ceb-Fip Model Code 1990." 1993.

[13] ACI211.1-91: "Standard Practice for Selecting Proportions for Normal, Heavyweight, and Mass Concrete", American Concrete Institute, ACI Committee 211, 2002

[14] ASTM C143/C143M-15, Standard Test Method for Slump of Hydraulic - Cement Concrete”, ASTM International, 2015

[15] BS EN12390-7:2009, "Testing hardened concrete. Density of hardened concrete", The Britisih Standards Institution, May 2009.

[16] BS EN12390-3:2009, "Testing hardened concrete. Compressive strength of test specimens", The British Standards Institution, 2009.

[17] ASTM C496/C496M-04, "Standard Test Method for Splitting Tensile Strength of Cylindrical Concrete Specimens", ASTM International, 2004.

[18] ASTM E1820-17, “ Standard Test Method for Measurement of Fracture Toughness”, ASTM International, June 2017.

[19] Z. Ahmad, H. M. Saman, and P. M. Tahir, "Oil palm trunk fiber as a bio-waste resource for concrete reinforcement," Int. J. Mech. Mater. Eng., vol. 5, no. 2, pp. 199-207, 2010.

[20] A. A. Raheem, A. A. Soyingbe, and A. J. Emenike, "Effect of Curing Methods on Density and Compressive Strength of Concrete," Cem. Concr. Compos., vol. 3, no. 4, pp. 55-64, 2013.

[21] B. Suhendro, "Toward green concrete for better sustainable environment," Procedia Eng., vol. 95, no. Scescm, pp. 305-320, 2014.

\section{PROFILES}

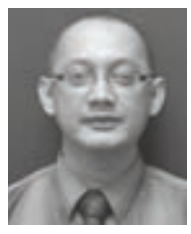

IR. DR. ABDUL AZIZ BN ABDUL SAMAD is a Professor in Structural Engineering, Faculty of Civil and Environmental Engineering, Universiti Tun Hussein Onn Malaysia. His research interest includes Repair and Strengthening of Structures, Interlocking Loadbearing Hollow Block, Green Concrete and Fracture Energy.

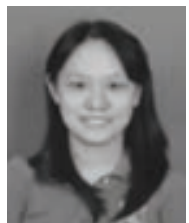

CINDY WONG YEAN THENG is a graduate from the Faculty of Civil and Environmental Engineering, Universiti Tun Hussein Onn Malaysia. She graduated with a 1st class Degree in Civil Engineering with honours. She is now working as a Civil Engineer with a consultant firm in Selangor. 


\section{PROFILES}

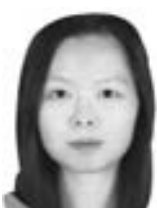

TIM EE CHING is a graduate from the Faculty of Civil and Environmental Engineering, Universiti Tun Hussein Onn Malaysia. She graduated with a 1st class Degree in Civil Engineering with honours. She is now working as a Civil Engineer with a consultant firm in Singapore.

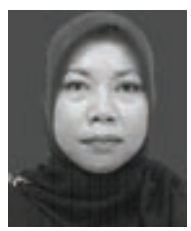

DR NORIDAH MOHAMAD is an Associate Professor, Faculty of Civil Engineering, Universiti Tun Hussein Onn Malaysia. Her research interest includes Precast Concrete Sandwich Panels, Repair and Strengthening of Structures, Foam Concrete, Self-Compacting Concrete (SCC).

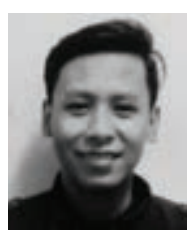

MUHAMMAD AFIQ TAMBICHIK is an on-going PhD student at the Faculty of Civil and Environmental Engineering, Universiti Tun Hussein Onn Malaysia. His research area is on the development of a sustainable building material focussing on green concrete utilizing agricultural and construction waste.

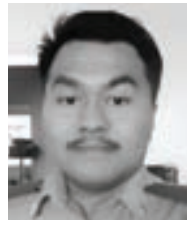

MOHAMAD ZULHAIRI MOHD BOSRO is an on-going PhD student at the Faculty of Civil and Environmental Engineering, Universiti Tun Hussein Onn Malaysia. His research area is on the design and development of green building technology focussing on an interlocking load bearing hollow block which utilizes agricultural and construction waste. 